\title{
BEHAVIORAL CONSEQUENCES OF CUSTOMERS' SATISFACTION WITH BANKING PRODUCTS AND SERVICES
}

\begin{abstract}
Florin-Lucian ISAC 1
Anca-Maria MILOVAN-CIUTA 2

Andrei DOBRE ${ }^{3}$

DOI: 10.1515/tjeb-2015-0017

The premise that consumer satisfaction determines behavioral models that positively influence business results, is accepted both in the academic and business environment. This research addresses the consequences of satisfaction from the customer's perspective, focusing on behaviors that customers of banks adopt as a result of satisfaction/dissatisfaction experienced from the performed transactions. Based on literature review, we have developed our own research model and tested the hypotheses formulated regarding the relationships formed between customer satisfaction and behavioral responses to customer satisfaction. For this purpose, we conducted a survey in which the investigated statistical population consists of customers who have completed at least one transaction with suppliers of banking products and services in the last six months. The sample gathered 511 persons using the snowball method, and respondents filled in questionnaires through online self-administration. We tested the research hypotheses using SPSS. Data analysis involved testing the reliability of the used measurement scales, score factors determination, testing the validity of constructs included in the research model, research hypotheses testing. In this article, in analyzing the relationship between customer satisfaction with banking products and services and its behavioral consequences, we take into consideration trust and supplier switching costs as moderator variables.
\end{abstract}

Keywords: $\quad$ Satisfaction; Trust; Word-of-Mouth; Complaints; Switching barriers.

JEL Classification: L30, M31.

${ }^{1}$ PhD, Aurel Vlaicu University, Arad, Romania.

${ }^{2}$ Lecturer PhD, West University of Timisoara, Timisoara, Romania.

${ }^{3}$ PhD Candidate, Bucharest University of Economic Studies, Bucharest, Romania. 


\section{Introduction}

Within both the academic and business environment, the premise that customers' satisfaction determines behavioral models that positively influence business results is accepted. The marketing literature consequently identifies customers' satisfaction as a key-factor for loyalty and re-buying goods and services from organizations.

In the marketing literature, customer satisfaction is an important determinant of the profitability of a company (Luo \& Homburg, 2007). Anderson et al. (1994), respectively Rust et al. (2002) highlight that customers' satisfaction has a positive impact on the indexes that express the financial performance of an organization. In other studies, researchers found that consumer satisfaction increases the value obtained by shareholders by increasing cash flow and reducing volatility (Fornell et al, 2006; Gruca \& Rego, 2005).

Most of the studies investigate this subject from the customer's perspective, approaching post satisfaction reactions and intentions. The most important observation, on this perspective, is that satisfaction increases customers' loyalty and influences future re-buying intentions and behaviors (Fornell et al., 1996; Mittal şi Kamakura,2001; Mittal et al.,1994, Olsen, 2002). Another mechanism through which satisfaction might improve the organization's profitability is linked to prices; researchers have come to the conclusion that very satisfied customers are willing to pay at bigger prices (Homburg et. al., 2005) and they are less sensitive to variations of the selling price.

Other studies have investigated the relationship between efficiency and customer satisfaction, Anderson et al. (1997) showing that consumer satisfaction positively influences sales by employees. It is plausible that customer satisfaction influences specific aspects of marketing activities productivity since consumer satisfaction induces behaviors such as word-of-mouth communication and companies that have customers who are highly satisfied during the transaction could register greater efficiency of investments made in marketing communications.

The researches on the customers' satisfaction topic have neglected its consequences on the organizations' employees. Among the exceptions there is the study of Ryan et al. (1996), which noticed that customers' satisfaction has a positive impact on the employees' satisfaction.

Companies with a higher level of customer satisfaction are more attractive employers and their human resources are more productive.

This present research approaches the consequences of satisfaction from the consumer's perspective, focusing on the behaviors that the banks' customers adopt as a consequence of their satisfaction/dissatisfaction with transactions.

DE GRUYTER OPEN
Timisoara Journal of Economics and Business | ISSN: 2286-0991 | www.tjeb.ro Year 2015 | Volume 8 | Issue 2 | Pages: 232-254 


\section{Literature Review}

Customer's satisfaction main consequence is customer loyalty. On this perspective, satisfaction should be a necessary and sufficient condition to develop loyalty for a bought service. Research on the relation between satisfaction and loyalty offer various results. Some studies have identified satisfaction as being the key factor in explaining loyalty (Anderson \& Fornell, 1994; Oliver \& Linda, 1981; Pritchard, 1991), while other studies suggest that customers' satisfaction is not enough to get them loyal (Cronin \& Taylor, 1992; Fornell, 1992; Oliva, Oliver \& MacMillan, 1992).

According to Hennig-Thurau and Klee (1997), studies which approach the relationship between customers' satisfaction and loyalty can be grouped into three different literature sections. The first segment comes from the literature dedicated to the management of services and it concerns the relationship on an aggregated level. These studies consider satisfaction as a customer's loyalty antecedent, which, in turn, influences the profitability of the company (Anderson et al., 1994; Heskett et al., 1994; Rust \& Zahoric, 1993).

The second literature segment studies the relationship between satisfaction and loyalty on an individual level and it targets customer retention and his/her intention of re-buying. This second segment of literature perceives loyalty as being influenced by satisfaction, although the structure of the relationship does not seem to be symmetrical and linear (Anderson \& Sullivan, 1993; Mittal et. al., 1998; Oliva et al., 1995).

The third literature segment, the narrowest, has focused on the relationship between satisfaction and loyalty on an individual level, using data from real buying situations (Bolton, 1998; Mittal \& Kamakura, 2001). This type of studies noticed a weak or insignificant relationship between satisfaction and re-buying behavior.

Satisfaction plays an important role in building trust, in order to maintain a relationship between the buyer and seller (Michell, Reast \& Lynch, 1998; Odekerken-Schroeder, Birgelen, Lemink, Ruyter \& Wetzels, 2000). On the other hand, Singh \& Sirdeshmukh (2000) make a distinction between trust that appears before the beginning of a transaction (pre-trust) and trust that appears after the transaction (post-trust).

Leisen and Hyman (2004) show that both satisfaction and the length of the relationship influence trust, supporting Bitner's opinion (1995), according to which trust is in a relationship with satisfaction along several episodes of the consumer-supplier relationship. Johnson and Grayson (2005) show that satisfaction with previous interactions adds to cognitive trust and it has nothing to do with affective trust. According to the authors, cognitive trust represents the customer's wish to rely on the competence and safety associated to the supplier, while affective 
Isac, F. L., Milovan-Ciuta, A. M., \& Dobre A. (2015). of Economics and Business

Behavioral consequences of customers' satisfaction with banking products and services

trust is the faith that a partner shows in the other partner based on feelings, faith which is generated by the level of concern that partner shows in solving the consumption issue.

Table 1. A synthesis of studies concerning customer's satisfaction consequences

\begin{tabular}{|c|c|}
\hline Customer's satisfaction consequence & Study \\
\hline \multicolumn{2}{|l|}{ A. Behavioral intentions } \\
\hline A1. Customer's commitment & $\begin{array}{l}\text { Gustafsson, Johnson \& Roos (2005) } \\
\text { Brown et al. (2005) } \\
\text { Liang \& Wang (2004) }\end{array}$ \\
\hline A2. Re-buying intentions & $\begin{array}{l}\text { Homburg, Hoyer \& Koschate (2005) } \\
\text { Mittal \& Kamakura (2001) } \\
\text { Szymanski \& Henard (2001) } \\
\text { Mittal, Ross \& Baldasare (1998) } \\
\text { Anderson (1994) } \\
\text { Anderson \& Sullivan (1993) } \\
\text { Oliver \& Swan (1989) } \\
\text { Oliver (1980) }\end{array}$ \\
\hline A3. The perception of price and the tendency of paying it & $\begin{array}{l}\text { Homburg, Hoyer \& Koschate (2005) } \\
\text { Homburg, Koschate \& Hoyer (2005) } \\
\text { Stock (2005) } \\
\text { Anderson (1996) }\end{array}$ \\
\hline \multicolumn{2}{|l|}{ B. Customer behaviors } \\
\hline B1. Customer's loyalty and re-buying behavior & $\begin{array}{l}\text { Homburg \& Fürst (2005) } \\
\text { Seiders et al. (2005) } \\
\text { Lam et al. (2004) } \\
\text { Liang \& Wang (2004) } \\
\text { Keiningham, Munn \& Evans (2003) } \\
\text { Kamakura et al. (2002) } \\
\text { Dholakia \& Moorwitz (2002) } \\
\text { Olsen (2002) } \\
\text { Mittal \& Kamakura (2001) } \\
\text { Bolton, Kanan \& Bramlett (2000) } \\
\text { Bolton \& Lemon (1999) } \\
\text { Bolton (1998) } \\
\text { Rust \& Zahoric (1993) } \\
\text { Fornell (1992) } \\
\text { Oliva, Oliver \& McMillan (1992) } \\
\text { La Barbera \& Mazurski (1983) }\end{array}$ \\
\hline $\begin{array}{l}\text { B2. Complaining behavior and word-of-mouth } \\
\text { communication }\end{array}$ & $\begin{array}{l}\text { Brown et al.(2005) } \\
\text { Szymanski \& Henard (2001) } \\
\text { Anderson (1998) } \\
\text { Ping (1993) } \\
\text { Richins (1983) } \\
\text { Bearden \& Teel (1983) }\end{array}$ \\
\hline B3. Customer giving up services & $\begin{array}{l}\text { Gustaffson, Johnson \& Roos (2005) } \\
\text { Capraro, Broniarczyk \& Srivastava (2003) } \\
\text { Dholakia \& Moorwitz (2002). }\end{array}$ \\
\hline
\end{tabular}

Source: adapted after Luo and Homburg, 2007:134.

Furthermore, Chiou and Droge's study results (2006) show that satisfaction and the perceived quality of services generate overall satisfaction and trust.

DE GRUYTER OPEN 
Concerning the direction of the relationship between satisfaction and trust, studies have shown that overall satisfaction generates trust (Ganesan, 1994; Selnes,1998), and, as a result, consumer's loyalty may be increased by building a reliable image (Chiou \& Droge, 2006).

Two-factor theory of customer satisfaction adapted from Herzberg 's two factor of motivation into marketing research Herzberg $(1968,1987$, in Liu et al., 2010) is applied to identify two categories of factors: "hygiene” factors and "satisfiers". Hygiene factors are those attributes that are expected by the customers as minimum requirements. Lack of hygiene factors will lead to dissatisfaction while having them will not necessary enhance customer satisfaction. Some general hygiene factors are credibility, delivery and accuracy. Satisfiers are those attributes that are little „extra”, such courtesy and empathy (Liu et al., 2010).

Customers' tendency to complain to sellers has been approached in the literature as a consumer mechanism to remove cognitive dissonance when the consumption experience is unsatisfactory (Oliver, 1987). Complaints have been approached as a mechanism of removing fear and frustration and as well as a mechanism of searching for recovery in case of failing experiences.

Within the relationship paradigm, complaining behavior is a strong signal that companies should consider. It offers the organization one last chance to retain a customer, if it reacts appropriately; and, on the other hand, it represents an ethical and legitimate act towards the customer. Generally, but not exclusively, the claiming behavior is one of customer's responses to the dissatisfaction felt in the post-buying phase.

An unsatisfied customer may adopt different responses; their taxonomy needs, in the first place, a distinction between the notions of response and action (Crié, 2003). The term of action involves a very specific behavior, while the response term contains ways which are not exclusively related to behavior, especially the change in attitude or inactivity.

A second useful distinction is offered by the type of entities to which the responses are directed: the public ones (sellers, producers, customer associations or legal action) and the private ones (family, friends, relatives).

Responses have different intensity according to the two dimensions and they can vary from inactivity to legal action, from the simple form of expressing dissatisfaction to getting compensations for their loss.

The disparity of these types of responses may be explained, firstly, by the cause and intensity of dissatisfaction, and, on secondly, by the nature and importance of the service. 
Isac, F. L., Milovan-Ciuta, A. M., \& Dobre A. (2015). of Economics and Business

Behavioral consequences of customers' satisfaction with banking products and services

Table 2. Literature synthesis on the nature of responses to dissatisfaction

\begin{tabular}{|c|c|}
\hline Author & The nature of responses \\
\hline Hirschman (1970) & Exit, Voice, Loyalty \\
\hline Day \& Landon (1977) & Public or private action, the response is not of behavioral nature \\
\hline Valle \& Krishnan (1978) & Private action, action straight to the producer, legal action, inaction \\
\hline Day $(1980,1984)$ & Searching for recovery, claiming, boycott \\
\hline Bearden \& Teel (1983) & Private response, claiming, contacting consumers' associations, legal action \\
\hline Richins (1987) & Forsaking, interpersonal verbal communication, claiming \\
\hline Singh $(1988,1990)$ & Claiming, private response, response addressed to a third party \\
\hline Singh \& Pandya (1991) & Forsaking, interpersonal verbal communication, claiming, action through a third party \\
\hline Maute \& Forrester (1993) & Forsaking, claiming, inaction \\
\hline
\end{tabular}

Source: Crié, 2001:47.

From the different types of responses to dissatisfaction, some of them are directly concerning the claiming behavior. The first conceptual basis for this post-buying behavior was founded in late 1970s (Day et al., 1981). Jacoby and Jaccard (1981) are defining it as an action started by individuals who imply the action of communicating something negative about a good or service both to a company or to a third party. Fornell and Wernerfelt (1987) consider that by complaining a client attempts to change an unsatisfactory situation. Singh (1988) suggests that this behavior, activated on an emotional level by the perception of dissatisfaction, is only a part of a general frame for responses to dissatisfaction, comprised of two dimensions. The first, totally or partially based on the actions initiated by the consumer, has a behavioral character, but it doesn't necessarily involve an action towards the organization. The second one refers to the lack of action coming from the customer.

The notion of claiming behavior includes a more general terminology which also involves the notions of protest, communication, recommendation to a third party or even boycott.

Kowalski (1996) argues that certain consumers claim not only because of dissatisfaction, but they try to get concessions from providers or producers.

Hirschman (1970) appreciated that there are three possible answers from the customers due to the decrease of the quality level of services provided by producers: renouncement, addressing or loyalty.

Renouncement, addressing, interpersonal verbal communication and a third party involvement are the four claiming behaviors frequently considered within literature. 
Renouncement refers to customers' decision of not buying anymore a product or a service, of not buying from a certain retailer or even from the manufacturer.

Addressing is the attempt to require recovery of the situation to a provider or a producer, which can be both written or verbal.

Communicating dissatisfaction to the family members and friends is the negative interpersonal verbal communication, usually presented as a warning for not buying a certain product.

Involving of a third party consists in contacting an external agency to solve the unsatisfying episode. This third party might be a group of customers or a legal representative.

Hueffner and Hunt (1994) mentioned another three claiming behaviors: revenge, avoidance and "grudge-holding".

Revenge is the process where the customer wants to get "even" with the seller. Possible manifestations of revenge may consist in destroying products and equipments, stealing, negative verbal interpersonal communication inside the store, putting products inside the store in inappropriate places. Both envy and avoidance are forms of an extended renouncement. The problem referring to the actual concept of giving up is that it doesn't have attached a temporal frame. Different customers may abandon the provider at different time sequences: some of them may return to buy the product one week after, others will never buy the product again. Renouncement is a short term phenomenon, avoiding is a medium term phenomenon, consisting in a deliberate attempt to "punish" the company. Reluctance is a more extreme phenomenon which can take a long time.

Informal interpersonal verbal communication (it will be also named viral communication, known with the acronym of WOM- "word-of-mouth communication") is one of the strongest forces on the market (Bansal \& Voyer, 2000), having a strong persuasive character and being effective (Bristor, 1990). It happens because the customers are rely more on informal communication sources and/or personal communication sources, than on formal and organizational sources, in taking the buying decisions.

The relationship between satisfaction and informal interpersonal verbal communication benefits from a substantial theoretical and empirical support in literature (Bitner, 1990; Athanassopoulos, Gounaris \& Stathakopoulos, 2001; Ranaweera \& Prabhu, 2003; Babin et al., 2005).

An unsatisfied customer will have the tendency of claiming, changing the provider or being involved in a negative informal interpersonal communication, (Zeelenberg \& Pieters, 2004). On 
the contrary, a satisfied customer will probably buy again the service or he/she will recommend it to others (Athanassopoulos, Gounaris \& Stathakopoulos, 2001; Yu \& Dean, 2001). Athanassopoulos, Gounaris \& Stathakopoulos (2001) have noticed that customer's satisfaction with banking services is positively associated with the act of positive informal interpersonal verbal communication. The same result had been obtained by Ranaweera and Prabhu (2003) in the investigation on using fixed dialing residential lines, respectively by Babin et al. (2005) in their study on restoration services customers.

Although the positive relationship between satisfaction and informal interpersonal verbal communication is supported by empirical studies (Richins, 1983; Halstead, 2002; Westbrook, 1987), respectively the satisfied customers are participating in communicative activities more than unsatisfied ones, there exists theoretical and practical support for an inverse relationship. According to these studies, unsatisfied customers have been participating in such activities more than satisfied ones (Holmes \& Lett, 1977; Swan \& Oliver, 1989; Zeelenberg \& Pieters, 2004). There are at least three explanations for these contradictory conclusions (Ladhari, 2007).

First, the researchers have been taking into consideration a variety of aspects for the evaluation of informal interpersonal verbal communication. These aspects include the number of contacts (Anderson, 1998; Halstead, 2002), the number of persons that have been communicated to (Holmes \& Lett, 1977), the frequency of the discussions to the others (Westbrook, 1987), the number of persons involved in discussion (Westbrook, 1987), the number of discussed matters (Westbrook, 1987), and the probability of discussing with others (Derbaix \& Vanhamme, 2003).

In the second place, numerous factors can encourage or discourage an individual in his/her commitment in many or less viral communication activities. These factors include the wish of warning a friend, neighbor or associate, the wish of reducing cognitive dissonance, the feelings of power and prestige, retention of transmitting bad news, the need of removing doubts about own buying action, the wish of increasing involvement into a desirable group (Harrison-Walker, 2001).

Third, financial, psychological, physical or social risks associated to buying actions may increase involvement and, subsequently, may determine increasing commitment in informal interpersonal verbal communication.

Hauser, Simester and Wernerfelt (1994), respectively Anderson and Sullivan (1993) have concluded that there is a negative relationship between the costs of switching the supplier and the customer's sensitivity at different satisfaction levels. Switching costs are very important factors for customers (Wieringa \& Verhoef, 2007) and they may be defined as costs involved by the change of a supplier with another one (Heide \& Weis, 1995). These costs may be monetary, non-monetary (time, effort, inconvenience) or emotional (Dick \& Basu, 1994). Failures in 
providing services represent the main causes of switching suppliers behaviors (Keaveney, 1995; Roos \& Gustafsson, 2007).

Yang and Peterson notices (2004) suggest that customer's loyalty may be generated by customer's satisfaction improvement and the offer of a higher service value, but the unsatisfied customers will have a higher desire of switching the service than satisfied customers (Crosby \& Stephens, 1987; Mittal \& Lasar, 1998; Rust \& Zahoric, 1993).

When the customers are unsatisfied of the value received in exchange of their money or they perceive an incorrectness of prices, they will develop their intention of switching the supplier (Athanassopoulos, 2000; Bansal, Taylor \& James, 2005; Homburg et al., 2005). On the other hand, satisfaction reduces the temptation to switch the provider (Colgate et al., 2007) and it also increases the chances of being loyal to the respective provider (Burnham, Frels \& Mahajan, 2003; Jones, Mothersbaugh \& Beatty, 2000).

Several studies have examined the association between customer satisfaction and service switching. The reasoning behind customers switching behavioural responses has been related to perceptions of quality in the banking industry, overall dissatisfaction in the insurance industry and service encounter failures in the retail industries (Rust \& Zahorik, 1993; Crosby \& Stephens, 1987; Kelley et al., 1993, in Athanassopoulos et al., 2001).

Investigation of switching behavior has raised the interest of researchers that studied the banking sector (Manrai \& Manrai, 2007). The very competitive banking industry, is concerned with this behavior, because a customer changing a bank reduces its profit and its shares (Clemes, Gan \& Zhang, 2010). Colgate and Hedge (2001), in a study on bank markets from Australia and New Zeeland, show the reasons for switching providers by the customers and they have ranked them in three main problematic areas for companies: the failure of the service, the prices and the refuse of services. In their study they show that the problems concerning the prices had the greatest impact on the switching behavior. Chakravarty et al. (2004) have examined the role of relationships between customers and their banks in determination with switching behavior. Based on the data gathered about American customers, they have shown that certain variables of the relationship have significantly decreased customers' determination of changing the bank. These variables are the length of relation with the bank, if they had or hadn't problems with the bank before and issues linked to the quality of their relation.

Keaveney (1995) has built the first model of switching behavior, identifying causal factors and proposing interaction effects among them. The author has identified seven reasons for switching behavior: price, lack of commodity, failure of the basic service, failure of business meeting, competitive matters, ethical matters, involuntary factors. Zeithaml et al. (1996) 
appreciated the quality of services as being negatively associated to the unfavorable behavioral intentions, as there is the tendency of changing the provider.

The reasons that stand at the basis of behavioral responses after switching the supplier have been linked to the perceptions on quality in the banking industry (Rust \& Zahoric, 1993), to overall satisfaction in the insurance industry (Crosby \& Stephens, 1987) and to retailers' failures in offering services (Kelley et al., 1993). Moreover, Bitner (1990) has studied the effects of time, money, constraints, access to information, lack of credible alternatives, switching costs and habits that can affect loyalty towards the service. Cronin and Taylor (1992) suggest that opportunity, a superior value received for money and availability might improve customer's satisfaction and, subsequently, the behavioral intentions.

Switching barriers are factors that make it difficult for a customer to change service providers (Jones et al., 2000), even when customers are not satisfied with the current service provider, customers may still remain with the provider because of potential financial and social loss and/or psychological burden (Fornell, 1992). Some of the factors that can increase switching barriers are search costs, transaction costs, learning costs, loss of loyal customer discounts, loss of established habits and risk of unknown (Fornell, 1992). The positive impact of switching barriers on repurchase intention has been confirmed (Colgate \& Lang, 2001; Jones et al., 2000, in Liu, 2010). If switching barriers such as troublesomeness of switching or loss of special treatment are high, customers are likely to stay with the same service provider to avoid potential costs and losses, even if the customers are not satisfied (Jones et al., 2000).

\section{Research Methodology}

\subsection{Research hypotheses and proposed research model}

Based on literature review, we have developed our own research model and tested the hypotheses formulated regarding the relationships formed between customer satisfaction and behavioral responses to customer satisfaction.

H1: Customer's satisfaction is in a direct relationship with loyalty.

In literature there is evidence that customer's satisfaction is an important predictor of loyalty (Anderson \& Sullivan, 1993; Fornell, 1992; Gustafsson, Johnson \& Roos, 2005; Liang \& Wang, 2004; Mittal \& Kamakura, 2001; Rust \& Zahorik, 1993).

H2: Customer's satisfaction is in a direct relationship with trust. 
H3: Customer's trust moderates the relationship between satisfaction and loyalty.

Satisfaction is an important factor in building trust and maintaining a relationship between the seller and buyer (Michell et al., 1998; Odekerken-Schroeder et al., 2000). In time, satisfaction reinforces the safety perceived towards the organization's services and it contributes to obtaining and developing trust between customers and sellers (Ganesan, 1994; Tax et al., 1998).

H4: Customer satisfaction is inversely related to complaint behavior.

The analysis lead by Szymanski and Henard (2001) revealed that medium correlation between satisfaction and complaint behavior is -0.34 . The complaints appear when "the customers are communicating their discontents in an explicit way to the company or to a third party, as a customer association or a governmental organization" (Zeelenberg \& Pieters, 2004, p.449). The complaint behavior is an action that results from the emotions produced by dissatisfaction in order to reduce frustration, anxiety, tension. The identified researches within literature show an inverse relationship between satisfaction and complaint behavior (Bearden \& Teel, 1983; Richins, 1983; Singh, 1988; Westbrook, 1987; Zeelenberg \& Pieters, 2004).

H5: There is a positive direct relationship between satisfaction and the tendency to positive interpersonal verbal communication.

Literature offers enough arguments to support the relationship between satisfaction and positive interpersonal verbal communication (Athanassopoulos et al., 2001; Bitner, 1990; Hartline \& Jones; Swan \& Oliver, 1989), while satisfaction, respectively dissatisfaction to a consumption experience are the main antecedents of WOM communication (Anderson, 1998; Bolton \& Drew, 1992; Herr et al., 1991; Schlesinger \& Heskett, 1991; Wangenheim \& Bayon, 2004; Wangenheim \& Bayon, 2007).

Within the analysis conducted by de DeMatos and Vargas Rossi (2008) there have been identified 89 studies where satisfaction is approached as an antecedent of informal interpersonal verbal communication, and the average correlation coefficient is 0.44 , so there is a relationship between customer's satisfaction and informal verbal interpersonal communication.

H6: Customer's satisfaction is inversely related to switching behavior/intention of switching the supplier.

H7: The costs of switching the supplier moderate the relationship between satisfaction and the switching supplier behavior. 
Isac, F. L., Milovan-Ciuta, A. M., \& Dobre A. (2015). of Economics and Business

Behavioral consequences of customers' satisfaction with banking products and services

\subsection{Research design}

The investigated statistic population comprises customers that have had at least one transaction with the providers of goods and services in the last six months.

In order to select the sample, we opted for a non-probability sampling method, the so-called "snowball" sampling, and the sample consists of 511 respondents. We resorted to the respondents' online self-administration of the questionnaire.

The main objective of the statistical data analysis is testing the hypotheses from the research model. Data analysis has involved completion of the following steps: testing the reliability of the used measurement scales, score factors determination, testing the validity of constructs included in the research model, research hypotheses testing.

The proposed research model is represented in Figure 1.

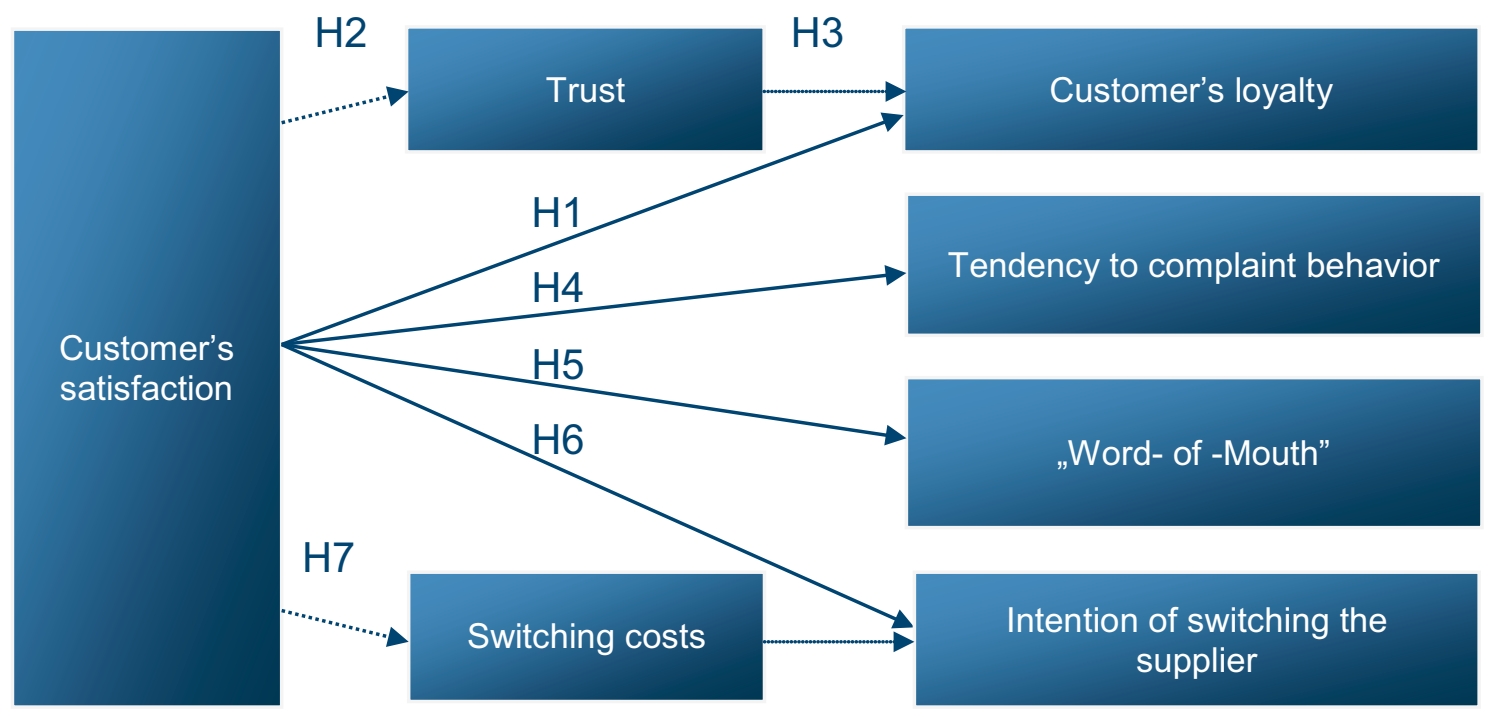

Figure 1. The proposed research model

Using factor analysis involved several steps. In the first phase, we checked the opportunity to apply factor analysis using the Kaiser-Meyer-Olkin indicator (KMO) and the Bartlett test of sphericity. We considered the use of factor analysis appropriate if the KMO coefficient was higher than 0.7and in the case of Bartlett sphericity test, we considered opportune the use of factorial analysis if the test signification level was under 0.05 .

In the second stage we conducted exploratory factor analysis for each construct in the research model. We studied load factor for each item, retaining only factors with higher load factor of 0.5. 
In the third stage we conducted a confirmatory factor analysis for each construct considering only previously retained items, each construct was examined using "eigenvalue" and total variance explained.

To test the validity of research constructs included in the model we determined the convergent validity and divergent validity.

We used the Pearson linear correlation coefficient as a statistical tool for analyzing the correlations between the items. To study the discriminant validity, we considered the linear Pearson correlation coefficient. In the factor analysis, we used the method of extracting principal component analysis factors, oblimin rotation method (to get correlated factors, where we have obtained more than one latent factor) and the criterion used to extract factors was Kaiser criterion (eigenvalue> 1) (as suggested by Costello \& Osborne, 2005).Thus, we have ensured the convergent validity of the constructs, as items retained show a high correlation with the factors they compose. All variables retained in the analysis fulfill the discriminant convergence criteria.

To test research hypotheses we used linear regression function, calculating the level of significance, the value of non-standardized regression coefficient function, the correlation coefficient (R) and the determination coefficient (R2).

Research hypotheses testing was performed using SPSS, technical and statistical tools used differ according to the type and nature of the relationship between these variables referred to by the hypothesis.

We studied the effects of moderators by comparing the regression function parameters in two situations: (1) when we considered only the antecedent variable and (2) when we also considered the antecedent and moderates variable. If antecedent variable parameter varies from one case to another, and the moderator in turn exerts a statistically significant effect on the dependent variable, we considered that we have identified a moderator effect.

In order to study the moderator effects, we have created a new variable, as an algebraic product between antecedent and moderator. In the linear regression, we considered as independent variables (1) the antecedent, (2) the moderator and (3) the calculated algebraic product. We have considered that a moderator effect exists if the (3) factor exerts a significant effect on the dependent variables.

For all regression functions determined, we appreciated the predictive power through correlation $(R)$ and determination $\left(R^{2}\right)$ coefficients. To study the intensity of the independent variable influence on the dependent variable, we reported to the standardized coefficient of the determinant regression function (Beta). 
Isac, F. L., Milovan-Ciuta, A. M., \& Dobre A. (2015). of Economics and Business

Behavioral consequences of customers' satisfaction with banking products and services

\section{Research Results and Discussion}

H1: Customer's satisfaction is in a direct relationship with loyalty.

$\mathrm{H} 1$ hypothesis is confirmed as the two variables are correlated, as shown by the correlation coefficient $(R=0.553)$, and the link between them is positive and statistically significant $(\beta=$ $0.553, p=0.000$ ). In addition, on the basis of the determination coefficient of 0.306 , we can say that $30.6 \%$ of the variance in customer loyalty variable is generated by the variable variance of overall satisfaction with the services of the bank.

Table 3. The results of the research hypotheses testing

\begin{tabular}{|c|c|c|c|c|c|c|}
\hline $\begin{array}{l}\text { Research } \\
\text { hypothesis }\end{array}$ & $\begin{array}{l}\text { Independent } \\
\text { variable }\end{array}$ & \multirow{2}{*}{$\begin{array}{c}\text { Dependent } \\
\text { variable } \\
\begin{array}{c}\text { Customer's } \\
\text { loyalty }\end{array}\end{array}$} & \multirow{2}{*}{$\begin{array}{c}\begin{array}{c}\text { Correlation } \\
\text { coefficient } \\
\text { (R) }\end{array} \\
0.553\end{array}$} & \multirow{2}{*}{$\begin{array}{c}\text { Determination } \\
\text { coefficient } \\
\text { (R2) }\end{array}$} & \multirow{2}{*}{$\begin{array}{c}\begin{array}{c}\text { Standardized } \\
\text { coefficient of } \\
\text { the regression } \\
\text { function } \\
(\beta)\end{array} \\
0.553\end{array}$} & \multirow{2}{*}{$\begin{array}{c}\begin{array}{c}\text { Significance } \\
\text { level (p) }\end{array} \\
0.000\end{array}$} \\
\hline H1 & $\begin{array}{l}\text { Overall satisfaction with } \\
\text { the bank's services }\end{array}$ & & & & & \\
\hline $\mathrm{H} 2$ & $\begin{array}{l}\text { Overall satisfaction with } \\
\text { the bank's services }\end{array}$ & $\begin{array}{l}\text { Customer's } \\
\text { trust }\end{array}$ & 0.601 & 0.361 & 0.601 & 0.000 \\
\hline H3 & Customer's trust & $\begin{array}{l}\text { Customer's } \\
\text { loyalty }\end{array}$ & & & 0.840 & 0.000 \\
\hline $\mathrm{H} 4 \mathrm{a}$ & $\begin{array}{l}\text { Overall satisfaction with } \\
\text { the bank's services }\end{array}$ & $\begin{array}{l}\text { Complaints } \\
\text { addressed to } \\
\text { the bank }\end{array}$ & 0.071 & 0.005 & -0.071 & 0.153 \\
\hline $\mathrm{H} 4 \mathrm{~b}$ & $\begin{array}{l}\text { Overall satisfaction with } \\
\text { the bank's services }\end{array}$ & $\begin{array}{l}\text { Complaints } \\
\text { addressed to } \\
\text { third parties }\end{array}$ & 0.288 & 0.081 & 0.288 & 0.000 \\
\hline $\mathrm{H} 4 \mathrm{c}$ & $\begin{array}{l}\text { Overall satisfaction with } \\
\text { the bank's services }\end{array}$ & $\begin{array}{c}\text { Private } \\
\text { complaints }\end{array}$ & 0.115 & 0.013 & -0.115 & 0.020 \\
\hline H5 & $\begin{array}{l}\text { Overall satisfaction with } \\
\text { the bank's services }\end{array}$ & $\begin{array}{c}\text { Informal } \\
\text { interpersonal } \\
\text { verbal } \\
\text { communication }\end{array}$ & 0.515 & 0.265 & 0.515 & 0.000 \\
\hline H6 & $\begin{array}{l}\text { Overall satisfaction with } \\
\text { the bank's services }\end{array}$ & $\begin{array}{l}\text { Switching } \\
\text { service provider } \\
\text { behavior }\end{array}$ & 0.238 & 0.057 & -0.238 & 0.000 \\
\hline \multirow[t]{3}{*}{$\mathrm{H} 7$} & $\begin{array}{l}\text { Overall satisfaction with } \\
\text { the bank's services }\end{array}$ & Switching & & & -0.240 & 0.000 \\
\hline & Switching costs & service provider & & & 0.017 & 0.737 \\
\hline & $\begin{array}{l}\text { Moderator effect of } \\
\text { switching costs }\end{array}$ & ellavior & & & -0.058 & 0.248 \\
\hline
\end{tabular}

Source: Authors' calculation.

DE GRUYTER OPEN 
Isac, F. L., Milovan-Ciuta, A. M., \& Dobre A. (2015). of Economics and Business

Behavioral consequences of customers' satisfaction with banking products and services

H2: Overall satisfaction with the bank's services is in a direct relationship with the customer's trust.

$\mathrm{H} 2$ hypothesis is confirmed because the link between the two variables involves a statistically significant correlation, significant level value being 0.000 . Also, the coefficient $\beta$ standardized regression function is 0.601 . The value of this coefficient is higher than 0 , which indicates that the bond between the two constructs is positive. In other words, with increasing overall satisfaction level with the services of the bank consumer trust increases as well. Based on other coefficients, we can draw two conclusions. First, between the two variables there is a correlation $(R=0.601)$. Second, $36.1 \%$ of the variance in the dependent variable is generated by the independent variable variance $\left(R^{2}=0.361\right)$.

H3: Customer's trust moderates the relationship between overall satisfaction with the bank's services and customer loyalty.

Based on the results presented in the above table, we may say that hypothesis no. 3 is confirmed, customer's trust being one of the moderator variables of the relationship between overall satisfaction with the bank's services and customer loyalty. We can observe that the direct relationship between bank services and customer's loyalty is statistically significant ( $\beta=$ $0.553, p=0.000$ ). Also, between satisfaction and trust there is a positive and significant relation, statistically $(\beta=0.601, p=0.000)$, and between trust and loyalty there also exists a statistically significant and positive link $(\beta=0.840, p=0.000)$.

When the multiple regression variable consumer trust is introduced, the effect of overall satisfaction with the services of the bank on consumer loyalty has a lower intensity and it becomes statistically insignificant $(\beta=0.050, p=0.147$ ). This result shows that the relationship between overall satisfaction with the services of the bank and customer loyalty is moderated by consumer trust.

H4: Overall satisfaction with the bank's services is reversely related to complaining behavior.

Following the results obtained in earlier stages of the process of statistical analysis, this assumption is split into three hypotheses.

The research hypotheses $4 a, 4 b$ and $4 c$ aim to analyze the link between overall satisfaction with the services of the bank and the three dimensions of complaining behavior (complaints addressed publicly to the bank, public complaints addressed to third parties and also private complaints). The following are the results gained from testing these three hypotheses. 
H4a: Overall satisfaction with the bank's services is reversely related to public complaints addressed to the bank

From the table above we can observe that hypothesis no. $4 a$ is rejected. Although the two constructs are correlated $(\mathrm{R}=0.071)$ and $0.5 \%$ from the variation of dependent variable is generated by the independent variable $\left(R^{2}=0.005\right)$, the link between overall satisfaction with the bank's services and public complaints addressed to the bank is statistically insignificant $(p=0.153)$.

H4b: Overall satisfaction with the bank's services is reversely related to public complaints addressed to third parties.

From the table above we can observe that hypothesis no. $4 \mathrm{~b}$ is rejected. Although the two variables are connected, a fact revealed by the value of correlation coefficient $(R=0.288)$, the link between overall satisfaction with the bank's services and public complaints addressed to third parties is statistically significant and positive $(\beta=0.288, p=0.000)$. Another conclusion coming from the results presented in the table above is that only $8.1 \%$ from the variation of dependent variable is generated by the variation of the independent variable $\left(R^{2}=0.081\right)$.

Hypothesis no. 4c: Overall satisfaction with the bank's services is reversely related to private complaints.

$\mathrm{H}$ 4c checks the relationship between overall satisfaction with the bank's services and private complaints. Hypothesis no. $4 \mathrm{c}$ is confirmed, because the relationship between the two variables involves a statistically significant correlation, the value of the significance level being 0.020 . Also, the value of regression function standardized coefficient $\beta$ is -0.115 . The value of this coefficient is inferior to zero, which shows us that the link between the two constructs is negative.

So, increasing the level of overall satisfaction with the bank's services, decreases the level of private complaints. We may state two conclusions. First, between the two variables there is a correlation $(R=0.115)$. Second, only $1.3 \%$ of the variation of dependent variable is generated by the variation of independent variable $\left(R^{2}=0.013\right)$.

H5: Overall satisfaction with the bank's services is in a direct relationship with informal interpersonal verbal communication (WOM).

We may conclude that hypothesis no. 5 is confirmed. Specifically, between the two variables there is a correlation ( $R=0.515)$, and $26.5 \%$ of the variation of dependent variable is generated by the independent variable $\left(R^{2}=0.265\right)$.

Timisoara Journal of Economics and Business | ISSN: 2286-0991 | www.tjeb.ro Year 2015 | Volume 8 | Issue 2 | Pages: 232-254 
Moreover, analyzing the value of the standardized coefficient of the regression function $(\beta=0.515)$ and the value of significance level $(p=0.000)$, we can conclude that the relationship between overall satisfaction with the bank's services and WOM is statistically positive and significant. Thus, increasing the level of overall satisfaction with the bank's services also increases the level of WOM and vice-versa.

H6: Overall satisfaction with the bank's services is reversely related to the switching bank behavior.

We may observe that hypothesis no. 6 is confirmed because the two variables are correlated, which is revealed by the correlation coefficient value $(R=0.238)$, the link between them is statistically negative and significant $(\beta=-0,238, p=0,000)$. Moreover, based on the determination coefficient value of 0.057 , we may state that $5.7 \%$ from the variation of switching bank behavior variable is generated by overall satisfaction with the bank's services.

H7: Switching bank costs moderate the relationship between overall satisfaction with the bank's services and switching behavior.

To test this hypothesis we created a new variable called moderator effect of switching bank costs. This new variable represents the algebraic product between antecedent variable (overall satisfaction with the services of the bank) and the moderator variable (switching costs).

In the above table we may observe that hypothesis no. 7 is rejected because between the new created variable (the moderator effect of switching bank costs) and the dependent variable (switching bank behavior) there is no statistically significant link $(p=0.248)$. First, the antecedent variable (overall satisfaction with the services of the bank) exerts a statistically significant and negative influence on switching bank behavior $(\beta=-0.240, p=0.000)$. Second, between the moderator variable (switching bank costs) and dependent variable (switching bank behavior) there is a statistically insignificant link $(p=0.737)$.

\section{Research Conclusions and Limitations}

The present research confirmed that overall satisfaction with bank services has a direct and significant impact on customer loyalty. This conclusion also emerged from the results of other previous studies. For example, Liang and Wang (2004) have shown that behavior al loyalty manifests when satisfaction, customer trust and customer commitment improve. In the Malaysian banking sector, Ndubisi, Malhotra and Wah (2009) have shown that customer satisfaction explained $50 \%$ of variance in customer loyalty.

The results obtained in this research suggest that banks, in order to have loyal customers should focus on aspects that help achieve a high level of satisfaction, but also on variables that 
determine a high level of trust among its customers. Overall satisfaction with the bank's services is of great importance because increasing its level will also increase consumer trust in the banking services provider. In turn, this will lead to a high level of customer loyalty towards the bank. This conclusion is also confirmed by other authors that show that in the case of lasting customer-provider relations, consumer trust is a better predictor of behavioral intentions than the customer's overall satisfaction (Garbarino \& Johnson, 1999).

Overall satisfaction with the bank's services is in a direct and positive relationship with the informal interpersonal verbal communication (WOM). This result is consistent with previous results research (Anderson, 1998; Bolton \& Drew, 1992; Herr et al., 1991; Wangenheim \& Bayon, 2004; Wangenheim \& Bayon, 2007). For example, Anderson (1998) showed that customers with a higher level of satisfaction engage to a greater extent in positive informal interpersonal verbal communication, recommending products from the company where they are customers. Moreover, empirical studies conducted by Wangenheim and Bayon (2007) in the business-to-business and business-to-consumer context, revealed that there is a direct and positive relationship between customer satisfaction and positive informal interpersonal verbal communication.

The conducted research revealed that overall satisfaction with the services of the bank is inversely related to the bank switching behavior. This is similar to results obtained by other researchers in their studies. Thus, the study by Athanassopoulos (2000) in the banking sector in Greece, showed that there is a negative relationship between customer satisfaction and the bank switching behavior. The same result was obtained by Manrai and Manrai (2007) that assessed satisfaction with the services of the bank based on six attributes. The outcome of the authors reveals that each of these attributes is negatively correlated with the bank switching behavior.

Within this paper we were unable to validate the hypothesis according to which the relationship between overall satisfaction with the services of the bank and the bank switching behavior is moderated by bank switching costs, even if previous research confirmed this hypothesis (Colgate et. al. 2007; Athanassopoulos et. al., 2001; Manrai \& Manrai, 2007). A possible explanation for the result obtained by us may be the nature of the considered moderator variable. According to Colgate et. al. (2007), when analyzing the reasons why a consumer decides to remain customer or give up the products of an organization we should take into consideration not only negative reasons behind this decision but also positive ones.

In our research, we approached complaint behavior as a three-dimensional construct that includes the following dimensions: public complaints addressed to the bank, public complaints addressed to third parties and private complaints. Our results are consistent with those of Day and Landon (1977, in Bearden \& Teela, 1983) and Singh (1988).The results obtained in this research are partially consistent with previous research results. For example, Zeelenberg and 
Pieters (2004) considered complaint behavior as a one-dimensional construct and showed that satisfaction has a negative effect on complaint behavior. Once the level of customer satisfaction increases,the customer's intention to make complaints about the provider's offerings diminishes. Even if Zeelenberg and Pieters (2004) considered complaint behavior as a onedimensional construct, they operationalized the construct based on four items reflecting its three dimensions that we approached individually in relation to overall satisfaction with the bank's services. Another study that confirms the negative relationship between satisfaction and complaint behavior was conducted by Bearden and Teela (1983) in the business-to-consumer context.

The results of this research prove that satisfaction is in a positive or a negative relationship with different types of answers from the customers within the banking sector: loyalty, trust, complain tendency, viral communication, the intention of switching the bank services provider. The existence of these relationships has strategic and tactical implications for marketing and customer relationship management: integrated marketing communication, management of complaints, carrying out activities that lead to greater trust between partners, providing benefits to attenuate the intention of switching the bank in case of dissatisfaction.

The limitations of this research are given, first of all, by the fact that sampling has been carried out through an empiric, non-probabilistic method. Secondly, online questionnaire administration has influenced the quality of responses, having no possibility to explain some terms that may not have been correctly understood by respondents: costs of switching, switching intention. Thirdly, this research would have been more relevant if other moderator variables had been taken into consideration for the relationship between satisfaction and its behavioral consequences: personal communication polarity, positive or negative; customer characteristics and overall attitude towards the banking sector.

\section{References}

Anderson, E.W., \& Sullivan, M. (1993). The Antecedents and Consequences of Customer Satisfaction for Firms. Marketing Science, 12(2), 125-143.

Anderson, E.W., Fornell, C., \& Lehmann, D.R. (1994). Customer Satisfaction, Market Share, and Profitability: Findings from Sweden. Journal of Marketing, 58(3), 53-66.

Anderson, E.W., Fornell, C., \& Rust, R. (1997). Customer satisfaction, Productivity and Profitability: Differences between Goods and Services. Marketing Science, 16(2), 129-145.

Anderson, E.W. (1998). Customer Satisfaction and Word-of-Mouth. Journal of Service Research, 1(1), 517.

Athanassopoulos, A. D. (2000). Customer Satisfaction Cues to Support Market Segmentation and Explain Switching Behavior. Journal of Business Research, 47(3), 191-207.

Athanassopoulos, A., Gounaris, S., \& Stathakopoulos, V. (2001). Behavioral Responses to Customer Satisfaction: An Empirical Study. European Journal of Marketing, 5/6, 687-707.

DE GRUYTER OPEN
Timisoara Journal of Economics and Business | ISSN: 2286-0991 | www.tjeb.ro Year 2015 | Volume 8 | Issue 2 | Pages: 232-254 
Babin,B.J., Lee,Y.-K., Kim, E.-J., \& Griffin, M. (2005). Modeling Consumer Satisfaction and Word-ofMouth: Restaurant Patronage in Korea. Journal of Services Marketing, 19, 133-139.

Bansal, S.H., \& Voyer, P.A. (2000). Word-of-Mouth Processes within a Services Purchase Decision Context. Journal of Service Research, 166-177.

Bearden, W. O., \& Teel, J. E. (1983). Selected Determinants of Consumer Satisfaction and Complaint Reports. Journal of Marketing Research, 20(2), 21-28.

Bitner, M. (1990). Evaluating Service Encounters: The Effects of Physical Surroundings and Employee Responses. Journal of Marketing, 54(4), 69-82.

Bitner, M. J. (1995). Building Service Relationships: It's All about Promises. Journal of the Academy of Marketing Science, 23(4), 246-251.

Bodet, G. (2008). Customer Satisfaction and Loyalty in Service: Two Concepts, Four Constructs, Several Relationships. Journal of Retailing and Consumer Services, 15, 156-162.

Bolton, R. N. (1998). A Dynamic Model of the Duration of the Customer Relationship with a Continuous Service Provider: The Role of Satisfaction. Marketing Science, 17(1), 45-65.

Bolton, R., \& Drew, J. H. (1992). Mittigating the Effect of Service Encounters. Marketing Letters, 3(1), 5770.

Bristor, J. M. (1990). Enhanced Explanations of Word-of-Mouth Communications: The Power of Relationships. Research in Consumer Behavior, 4, 51-83.

Burnham, T. A., Frels, J. K., \& Mahajan, V. (2003). Consumer Switching Costs: A Typology, Antecedents and Consequences. Journal of Academy of Marketing Science, 31(2), 109-126.

Chakravarty, S., Feinberg, R., \& Rhee, E. Y. (2004). Relationships and Individuals Bank Switching Behavior. Journal of Economic Psychology, 25, 507-527.

Chou, J. S., \& Droge, C. (2006). Service Quality, Trust, Specific Asset Investment and Expertise: Direct and Indirect Effects in a Satisfaction - Loyalty Framework. Journal of The Academy of Marketing Science, 43, 613-627.

Clemes, M. D., Gan, C., \& Zhang, D. (2010). Customer Switching Behaviour in the Chinese Retail Banking Industry. International Journal of Bank Marketing, 28(7), 519 - 546.

Colgate, M., Tong, V. T.-U., Lee, C. K.-C., \& Farley, J. U. (2007). Back From the Brink: Why Customers Stay. Journal of Service Research, 9(3), 211-228.

Creswell, J. W. (2003). Research Design: Qualitative, Quantitative and Mixed Methods Approaches. Second Edition, Sage Publications.

Crié, D. (2001). Un cadre conceptuel d'analyse du comportement du reclamation. Recherche et Applications en Marketing, 16(1),45-63.

Crié, D. (2003). Consumer's Complaint Behavior. Taxonomy, Typology and Determinants: Towards a Unified Ontology. Database Marketing and Customer Strategy Management, 11(1), 60-79.

Cronin, J. J. Jr., \& Taylor, S. T. (1992). Measuring Service Quality: A Reexamination and Extension. Journal of Marketing, 56, 55-68.

Crosby, L. A., \& Stephens, N. (1987). Effects of Relationship Marketing on Satisfaction, Retention, and Prices in the Life Insurance Industry. Journal of Marketing Research, 24 (4), 404-411.

De Matos, C.A., \& Rossi, C.A. (2008). Word-of-Mouth Communication in Marketing: A Meta-Analytic Review of the Antecedents and Moderators. Journal of the Academy of Marketing Science, 36, 578-596.

Derbaix, C., \& Vanhame, J. (2003). Inducing Word-of-Mouth by Eliciting Surprise - A Pilot Investigation. Journal of Economic Psychology, 24(1), 99-116.

Dick, A. S., \& Basu, K. (1994). Customer Loyalty: Toward an Integrated Conceptual Framework. Journal of The Academy of Marketing Science, 22(2), 99-113.

DE GRUYTER OPEN 
Fornell, C., \& Wernerfelt, B. (1987). Defensive Marketing Strategy by Customer Complaint Management: A Theoretical Analysis. Journal of Marketing Research, 24(4), 337-346.

Fornell, C. (1992). A National Customer Satisfaction Barometer: The Swedish Experience. Journal of Marketing, 56, 6-21.

Fornell, C., Johnson, M. D., Anderson, E. W., Cha, J., \& Bryant, B. (1996). The American Customer Satisfaction Index: Description, Findings and Implications. Journal of Marketing, 60, 1996, 718.

Fornell, C., Mithas, S., Morgeson III, F. V., \& Krishnan, M. S. (2006). Customer Satisfaction and Stock Prices: High Returns, Low Risk. Journal of Marketing, 70(1), 3-14.

Ganesan, S. (1994). Determinants of Long-Term Orientation in Buyer-Seller Relationships. Journal of Marketing, 58(2), 1-19.

Garbarino, E., \& Johnson, M. S. (1999). The Different Roles of Satisfaction, Trust and Commitment in Customer Relationship. Journal of Marketing, 63(2), 70-87.

Gruca, T. S., \& Rego, L. L. (2005). Customer Satisfaction, Cash Flow, and Shareholder Value. Journal of Marketing, 69(3), 115-130.

Halstead, D. (2002). Negative Word-of-Mouth: Substitute for or Supplement to Consumer Complaints. Journal of Consumer Satisfaction, Dissatisfaction and Complaining Behavior, 15, 1-12.

Harrison-Walker, L. J. (2001). The Measurement of Word-of-Mouth Communication and Investigation of Service Quality and Customer Commitment as Potential Antecedents. Journal of Service Research, 4(1), 60-75.

Hauser, J. R., Simester, D. I., \& Wernerfwlt, B. (1994). Customer Satisfaction Incentives. Marketing Science, 13(4), 327-350.

Heide, J. B., Weiss, A. M. (1995). Vendor Consideration and Switching Behavior for Buyers in HighTechnology Markets. Journal of Marketing, 59, 30-43.

Hennig-Thurau, T., \& Klee, A. (1997). The Impact of Customer Satisfaction and Relationship Quality on Customer Retention: A Critical Reassessment and Model Development. Psychology and Marketing, 14(8), 737-764.

Herr, P.M., Kardes, F. R., \& Kim, J. (1991). Effects of Word-of-Mouth and Product Attribute Information on Persuasion: An Accessibility Diagnosticity Perspective. Journal of Consumer Research, 17(4), 54-62.

Heskett, J. L., Jones, T. O., Loveman, G. W., Sasser, W. E., \& Schlesinger, L. A. (1994). Putting the Service Profit Chain to Work. Harvard Business Review, 72(2), 164-170.

Hirschman, A. O. (1970). Exit, Voice and Loyalty. Responses to Decline in Firms, Organizations and States. Cambridge, MA: Harvard University Press.

Holmes, J. D., \& Lett, Jr. J. D. (1977). Product Sampling and Word of Mouth. Journal of Advertising Research, 17(10), 35-39.

Homburg, C., Koschate, N., \& Hoyer, W.D. (2005). Do Satisfied Consumers Pay More? A Study of the Relationship between Customer Satisfaction and Willingness To Pay. Journal of Marketing, 69(2), 84-97.

Huefner, J. C., \& Hunt, K. H. (1994). Extending the Hirschman Model: when Voice and Exit Don't Tell the Whole Story. Journal of Consumer Satisfaction, Dissatisfaction and Complaining Behavior, 7(1), 267-270.

Jacoby, J., \& Jaccard, J. J. (1981). The Sources, Meaning, and Validity of Consumer Complaint Behavior: A Psychological Analysis. Journal of Retailing, 57, 4-24.

Johnson, D., \& Grayson, K. (2005). Cognitive and Affective Trust in Service Relationships. Journal of Business Research, 58(4), 500-507. 
Jones, M. A., \& Suh, J. (2000). Transaction-Specific Satisfaction and Overall Satisfaction: An Empirical Analysis. Journal of Services Marketing, 14(2), 147-159.

Jones, M. A., Mothersbaugh, D. L., \& Beatty, S. E.(2000). Switching Barriers and Repurchase Intentions in Services. Journal of Retailing, 76(2), 259-274.

Keaveney, S. M. (1995). Customer Switching Behavior in Service Industries: An Exploratory Study. Journal of Marketing, 59(2), $71-82$.

Kelley S. W, Hoffman, K. D., \& Davis, M.A. ( 1993). A Typology of Retail Failures and Recoveries. Journal of Retailing, 69(4), 429-52.

Kowalski, R. M. (1996). Complaints and Complaining: Functions, Antecedents and Consequences. Psychological Bulletin, 119(2), 179-96.

Ladhari, R. (2007). The Effect of Consumption Emotions on Satisfaction and Word-of-Mouth Communications. Psychology and Marketing, 24(12), 1085-1108.

Leisen, B., \& Hyman, M.R. (2004). Antecedents and Consequences of Trust in a Service Provider. The Case of Primare Care Physicians. Journal of Business Research, 30(4), 10-16.

Liang, C. J., \& Wang, W. H. (2004). Attributes, Benefits, Customer Satisfaction and Behavioral LoyaltyAn Integrative Research of Financial Services Industry in Taiwan. Journal of Services Research, $4(1), 57-91$.

Liu, Ch.T., Guo, Y. M., \& Lee, C. H. (2010). The Effects of Relationship Quality and Switching Barriers on Customer Loyalty. International Journal of Information Management, 31, 71-79.

Luo, X., \& Homburg, C. (2007). Neglected Outcomes of Customer Satisfaction. Journal of Marketing, 71(4), 133-149.

Manrai, L. A., \& Manrai, A. K. (2007). A Field Study of Customer's Switching Behavior for Bank Services. Journal of Retailing and Consumer Services, 14, 208- 215.

Michell, P., Reast, J., \& Lynch J. (1998). Exploring the Foundations of Trust. Journal of Marketing Manangement, 14, 159-172.

Mittal, V., Ross, W. T., \& Baldasare, P.M. (1998). The Asymmetric Impact of Negative and Positive Attribute-Level Performance on Overall Satisfaction and Repurchase Intentions. Journal of Marketing, 62(1), 33-47.

Mittal, V., \& Kamakura, W. (2001). Satisfaction, Repurchase Intent and Repurchase Behavior: Investigating The Moderating Effect of Customer Characteristics. Journal of Marketing Research, 38, 131-142.

Ndubisi, N. O., Malhotra, N. K., \& Wah, C. K. (2009). Relationship Marketing, Customer Satisfaction and Loyalty: A Theoretical and Empiric al Analysis from an Asian Perspective. Journal of International Consumer Marketing, 21, 5-16.

Odekerken-Schroeder, G., Birgelen, M., Lemink, J., Ruyter, K., \& Wetzels, M. (2000). Moments of Sorrow and Joy: An Empirical Assessment of the Complementary Value of the Critical Incidents in Understanding Customer Service Evaluations. European Journal of Marketing, 34(1), 107-125.

Oliva,T. A., Oliver, R. L., \& MacMillan, I. C. (1992). A Catastrophe Model for Developing Service Satisfaction Strategies. Journal of Marketing, 56, 83-95.

Oliver, R. L. (2010). Satisfaction. A Behavioral Perspective on The Consumer. Second Edition, M.E. Sharpe.

Oliver, R. L., \& Linda, G. (1981). Effect of Satisfaction and Its Antecedents on Consumer Preference and Intention, in K. B. Monroe (Ed.) Advances in Consumer Research (pp. 88-93). Volume 08, Ann Arbor, MI: Association for Consumer Research.

Oliver, R. L. (1987). An Investigation of the Interrelationship Between Consumer (Dis) Satisfaction and Complaint Reports, in M. Wallendorf \& P. Anderson (Eds.) Advances in Consumer Research (pp.218-222). Volume 14, Provo, UT: Association for Consumer Research. 
Olsen, S. O. (2002). Comparative Evaluation and the Relationship Between Quality, Satisfaction, and Repurchase Loyalty. Journal of the Academy of Marketing Science, 30 (3), 240-249.

Pritchard, M. P. (1991). Development of The Psychological Commitment Instrument (PCI) for Measuring Travel Service Loyalty. Doctoral Dissertation, University of Oregon.

Ranaweera, C., \& Prabhu, J. (2003). On the Relative Importance of Customer Satisfaction and Trust as Determinants of Customer Retention and Positive Word of Mouth. Journal of Targeting, Measurement and Analysis for Marketing, 12, 82-90.

Richins, M.L. (1983). Negative Word-of-Mouth by Dissatisfied Consumers: A Pilot Study. Journal of Marketing, 47(1), 68-78.

Roos, I., \& Gustafsson, A. (2007). Understanding Frequent Switching Patterns. Journal of Service Research, 10(1), 93-108.

Ryan, A. M., Schmit, M. J., \& Johnson, J. (1996). Attitudes and Effectiveness: Examining Relations at an Organizational Level. Personnel Psychology, 49(4), 853-882.

Rust, R. Z., \& Zahorik, A. J. (1993). Customer Satisfaction, Customer Retention and Market Share. Journal of Retailing, 69(2), 193-215.

Rust, R. T., Zahorik, A. J., \& Keininghamn, T. L. (1994). Return on Quality. Chicago, IL: Probus Publishing.

Rust, R. T., Moorman, Ch., \& Dickson, P. R. (2002). Getting Return on Quality: Revenue Expansion, Cost Reduction, or Both?. Journal of Marketing, 65(4), 7-24.

Selnes, F. (1998). Antecedents and Consequences of Trust and Satisfaction in Buyer-Seller Relationships. European Journal of Marketing, 32(3/4), 305-322.

Singh, J. (1988). Consumer Complaint Intentions and Behavior: Definitional and Taxonomical Issues. Journal of Marketing, 52, 93-107.

Singh, J., \& Sirdeshmukh, D. (2000). Agency and Trust Mechanisms in Consumer Satisfaction and Loyalty Judgments. Journal of The Academy of Marketing Science, 28(1), 150-167.

Szymanski, D. M., \& Henard, D. H. (2001). Customer Satisfaction: A Meta-Analysis of the Empirical Evidence. Journal of The Academy of Marketing Science, 29(1), 16-35.

Wangenheim, F., \& Bayon, T. (2004). Satisfaction, Loyalty and Word of Mouth within the Customer Base of a Utility Provider: Differences between Stayers, Switchers and Referral Switchers. Journal of Consumer Behavior, 3(3), 211-220.

Wangenheim, F., \& Bayon, T. (2007). The Chain from Customer Satisfaction via Word-of-Mouth Referrals to New Customer Acquisition. Journal of the Academy of Marketing Science, 35, 233-249.

Westbrook, R. A. (1987). Product/Consumption-Based Affective Responses and Postpurchase Processes. Journal of Marketing Research, XXIV, 258-270.

Wieringa, J. E., \& Verhoef, P. C. (2007). Understanding Customer Switching Behavior in a Liberalizing Service Market. An Exploratory Study. Journal of Service Research, 10(2), 174-186.

Yu, Y.T., \& Dean, A. (2001).The Contribution of Emotional Satisfaction to Consumer Loyalty, International Journal of Service Industry Management. 12(3), 234 - 250.

Zeelenberg, M., \& Pieters, R. (2004). Beyond Valence in Customer Dissatisfaction: A Review and New Findings on Behavioral Responses to Regret and Disappointment in Failed Services. Journal of Business Research, 57(4), 445-455.

Zeithaml, V. A., Berry, L. L., \& Parasuraman, A. (1996). The Behavioural Consequences of Service Quality. Journal of Marketing Management, 60(April), 31-46. 